\title{
Det rådsdemokratiske ideal og protesten som selvorganisering
}

af BENJAMIN ASK POPP-MADSEN

SLAGMARK \# 7 I

SIDER: I95-2IO

I de senere år - fra den globale finanskrise med start i 2008 over Occupybevægelsen i USA, det arabiske forår og fremgangen til politiske bevægelser som spanske Podemos og græske Syriza - er protester imod ulighed og manglende politisk indflydelse igen blomstret op. ${ }^{1}$ Et gennemgående tema i disse protester har været kritikken af det repræsentative demokrati og de politiske eliters manglende evne til at varetage befolkningens interesser. I kan ikke reprcesentere os! var sloganet under den russiske opstand i 2012, på Tahrirpladsen i Kairo var det Nok!, i Athen på Syntagma-pladsen lød kampråbet Nok er nok! og i Spanien var kravet Reelt demokrati!. I Tyrkiet lød parolen Vi har fået nok!, i Brasilien De representerer os ikke! og i USA det nu kendte Vi er de 99 procent!. ${ }^{2}$ Protesterne peger på en grundlæggende utilfredshed med de politiske eliters håndtering af den økonomiske krise og det repræsentative systems evne til at løse almindelige menneskers problemer. Derfor har protesterne oftest antaget en anti-institutionel form. Demonstranterne har ignoreret de etablerede kanaler for politisk deltagelse og i stedet opfattet gaderne og pladserne, fremfor stemmeboksene og partierne, som oplagte steder for politisk deltagelse. 
Hvad kendetegner protesterne, der er vokset frem efter den globale finanskrise? Peger protesterne imod noget radikalt andet end det repræsentative demokrati? Denne artikel kigger nærmere på protesterne og de dominerende fortolkninger af dem. Da protesterne er politiske fænomener i schmittiansk forstand, dvs. polemiske fænomener, så kan de, i de fortolkninger, som oftest fremsættes i offentligheden, inddeles i for og imod, i negative og positive versioner. Trods den positive eller negative ladning centrerer fortolkninger sig dog om idéen om protesten som begivenhed: På den ene side hævdes det - blandt andet fra den indflydelsesrige politolog og politiske kommentator Ivan Krastev (2014) - at protesterne er problematiske, fordi de udelukkende opfatter sig selv som begivenheder og ikke formulerer et sammenhængende alternativ til det repræsentative demokrati. På den anden side hævdes det fra toneangivende tænkere som Slavoj Žizek (2012) og Alain Badiou (2012b), at protesternes styrke netop ligger i deres karakter som begivenhed - som omstyrtende, spontane momenter, der ikke kan institutionaliseres. I artiklen vil jeg argumentere for, at et fokus på protesten som begivenhed skygger for en anden vigtig forståelse af protesterne, nemlig protesten som selvorganisering: Protesten som konstituering af permanente og autonome politiske strukturer ved siden af det repræsentative demokrati.

Til at udfolde denne forståelse af protesten som selvorganisering vil jeg benytte den rådsdemokratiske tradition hos Hannah Arendt og Cornelius Castoriadis som prisme. Denne tradition har specifikt øje for de institutionelle frembringelser - såsom kollektivt fælleseje, decentrale nabolagsforsamlinger og demokratisk kontrol - som revolutionære praksisser ofte har frembragt. Det er således Arendts argument, at den revolutionære tradition oftest har set revolutionen som begivenhed og derfor ikke skelner mellem frigørelse og frihed (Arendt, 2012, s. 138-139). Hvor frigørelsen knytter sig til protesten og begivenheden, så er friheden - som er revolutionens egentlige mål - forbundet med et stabilt, institutionelt system for varig politisk deltagelse. Både Arendt og Castoriadis er derfor optagede af den opblomstring af nabolags-, fabriksog arbejderråd, der opstod i de moderne revolutioner fra Den Amerikanske Revolution og frem, og de opfattede begge rådene som deltagelsesdemokratiske institutioner, hvor borgerne kunne generobre ejerskabet over deres eget liv, hvor selvbestemmelse kunne erstatte elitestyre og apati og hvor politisk 
frihed gennem deltagelse kunne realiseres. Jeg vil argumentere for det frugtbare $i$ at se nutidens protester og den alternative politiske virkelighed de producerer som aktualiseringer af de rådsdemokratiske temaer, som Arendt og Castoriadis slår an. Om end nutidens protester ikke direkte henviser til rådsdemokratiet, så kan der i skismaet mellem protesten som begivenhed $\mathrm{og}$ protesten som selvorganisering findes centrale rådsdemokratiske elementer, der kan øge forstålsen af protesternes betydning. Som nævnt, med reference til Arendt, indeholder revolutionen både begivenhedens uforudsigelighed og selvorganiseringens permanens og ved at betone selvorganiseringen fremfor begivenheden, vil artiklen påpege 2011-protesternes mulighed for at skabe blivende institutioner for politisk deltagelse snarere end deres omvæltende karakter.

Mit argument er struktureret i tre dele: Først fremsætter jeg to fortolkninger af nutidens protester, der begge centrerer sig om protesten som begivenhed om end de valoriserer den forskelligt. Dernæst udlægger jeg Arendts og Castoriadis idéer om rådsdemokrati. Afslutningsvis diskuterer jeg, hvorledes protesternes selvorganisering kan ses som en aktualisering af rådsdemokratiske idéer.

I evalueringen af nutidens protester og sociale bevægelsers kamp for forandring er opfattelsen af protesten som begivenhed tydelig. I bogen Democracy Disrupted: The Politics of Global Protest (2014) analyserer Ivan Krastev betydningen af nutidens protester imod den globale finanskrise. Selvom Krastev anerkender 2011-protesterne som legitime vredesudbrud, så er han kritisk overfor deres anti-institutionelle karakter og manglende ideologiske forankring. Uden færdigformede alternativer og ambitioner om at indgå i demokratisk dialog gennem de etablerede kanaler, peger protesterne ifølge Krastev ikke udover begivenhederne selv. "Hvad der slår enhver iagttager af den nye bølge af revolutionær politik er, at det er en revolution uden en ideologi og uden et projekt. Protesten i sig selv synes at være det strategiske mål for de protesterende" (Krastev, 2014, s. 3). Protesternes fokus på begivenheden, på negationen fremfor den positive fremtidsversion, bekræfter for Krastev deres anti-institutionelle og anti-establishment karakter. Protesterne vil ikke forme 
koalitioner, vælge repræsentanter og stille krav til systemisk forandring, som tidligere tiders sociale bevægelser har villet: "I dag er der næppe nogen, der er interesseret i systemet [...]. Demonstranterne forstår sig selv som et alternativ til repræsentativt demokrati. Men hvad er alternativet? Demonstranterne har ingen forslag ud over selve protesthandlingen." (Krastev 2014: s. 19, 31) Fordi protesterne ikke sker på baggrund af et positivt formuleret alternativ til repræsentativt demokrati, så opfatter Krastev protesterne som problematiske for den demokratiske proces. Krastev sammenligner - via en lidt tvivlsom historisk analogi (se note 4) - nutidens protester med den strategi de romerske plebejere anvendte, da de under konflikten med patricierne fortrak til Aventinerhøjen og dermed valgte exit fremfor voice, ${ }^{3}$ dvs. fravalgte demokratisk deliberation som politisk redskab. ${ }^{4}$ Denne strategi har ifølge Krastev alvorlige konsekvenser, da den afsporer den demokratiske samtale, destabiliserer de legale kanaler for politik og omstyrter uden at opbygge:

På trods af de utallige fremvisninger af borgerånd og politisk idealisme, samt de inspirerende videoer og farverige udtryk for modkulturel fantasi, så er protesterne ikke løsningen på 'der ikke er noget alternativ'politikken [...]. Revolutioner behøver ideologi som ilt og brændstof og protesterne har ingen ideologi eller alternativ vision for fremtiden. Demonstranterne forstyrrer demokratiet. (Krastev 2014: s. 75, 76-77)

Protesterne fra 2011 og frem er således ifølge Krastev praksis uden teori, handlinger uden koncepter - de er kort sagt begivenheder; spontane forsamlinger af mennesker på pladser og gader, der hovedsageligt fungerer som tegn på afmagt.

I modsætning til Krastev findes også en positiv evaluering af protesterne som begivenhed. Hos toneangivende tænkere på den intellektuelle venstrefløj, som Slavoj Žizek og Alain Badiou, har begrebet om begivenheden stået stærkt de senere år. Både Žizek og Badiou har arbejdet indgående med begivenheden filosofisk (Badiou, 2012a; Žizek, 2014), hvor begrebet oftest forstås som det uforudsigelige og spontane moment, der overskrider den umiddelbare virkeligheds beskaffenhed og udkaster nye koordinater, hvori denne virkelighed - den sproglige, etiske, moralske, politiske, religiøse eller 
$ø$ konomiske - kan udspille sig. Midt under de verdensomspændende protester fra 2011 og frem, udgav begge tænkere skrifter om protesten som specifik politisk begivenhed. Modsat Krastev anser Žizek det anti-institutionelle element for protesternes styrke. Protesterne er netop "en begivenhed, en indtrængen af det umulige-Reelle i vores almindelige virkelighed, der momentant suspenderer enhver årsagssammenhæng" (Žizek, 2012, s. 130). Ved at insistere på den ulige fordeling af byrderne forårsaget af den globale finanskrise gennem fysisk forsamling på symbolske positioner (Wall Street, Syntagma, Tahrir) og uden at formulere kritikken af det bestående i et politisk sprog, der allerede er konstrueret til fordel for status quo, får protesterne deres begivenhedsstruktur. Da alle "radikale forandringer finder sted udenfor sfæren af legalitet", så må der ses bort fra de normale demokratiske procedurer, da disse altid "er en del af det 'borgerlige' statsapparat" (Žizek, 2012, s. 87). Hvis protesterne mister deres begivenheds-lignende struktur og inficeres med legalitet og proces, "blokereres der for enhver radikal transformation" (Žizek, 2012, s. 87). Derfor, ifølge Badiou, er "fjenden i dag hverken Imperiet eller Kapitalen. Det er Demokratiet" (Badiou, 2012a, s. xxviii). Repræsentative, demokratiske institutioner ødelægger, hvad Badiou kalder for 'den politiske sandhedsprocedure', der finder sted i ikke-institutionaliserede oprør og begivenheder i konflikt med det bestående (Badiou, 2012b, s. 85). Den egentlige politiske sfære består således for Badiou af spontane græsrodsorganisationer og sagspecifikke forsamlinger, ikke af formelle institutioner og etablerede aktører.

Vigtigheden af de senere års protester er således ifølge Žizek og Badiou, at de i stedet for at stille krav om at blive integreret i den etablerede politiske proces, hvilket ville frarøve protesterne deres transformerende potentiale, insisterer på ikke at formalisere sig. I stedet for at mobilisere krav formuleret i liberalismens rettighedssprog, så er protesternes styrke, at de som begivenheder muliggør konstitueringen af nye virkeligheder.

Hvor den demokratiske proces for Krastev trues af protesternes kortsynede praksis og manglende ambition om at forbinde sig til det etablerede politiske system, så er det netop dette etablerede sæt af repræsentative institutioner, som protesterne - hvis de skal fungere som radikale forandringer - skal styre udenom ifølge Žizek og Badiou. 
Begge disse fortolkninger synes at være utilstrækkelige. Ved hovedsageligt at fokusere på protesten som begivenhed - enten som illegal og uproduktiv eller som indstiftende og frugtbar - overses det, at protesterne immanent i deres organisationsmåde allerede institutionelt og ideologisk rækker udover begivenheden selv. Ved at forstå protesten som begivenhed reificeres det hierarki og elitisme, som protesterne vender sig imod: For Krastev kan en vellykket revolution kun finde sted via oplyste, intellektuelle demonstranter, der formår at oversætte mængdens larm til velformulerede lovforslag; for Žizek og Badiou kalder begivenhedens inhærente uregerlighed på en opdatering af proletariatets diktatur og den professionelle fortrop af fuldtidsrevolutionære (Badiou, 2012b, s. 47; Žižek, 2012, s. 266). For at opnå grundlæggende politiske forandringer kræves der "ikke massedemokrati overalt, men i stedet dets dialektiske modsætning: et overgangsdiktatur, som var uforsonligt og afgrænset" (Badiou, 2012b, s. 45).

I begge tilfælde undervurderes de politiske institutioner, der fremvokser autonomt af mængdens politiske handlinger og som ikke behøver en elite for at manifestere sig.

Men opfattes protesterne virkeligbedst som begivenheder? Protestbevægelserne i Europa og USA organiserer sig ofte gennem lokale, decentrale institutioner med direkte deltagelse og kollektiv selvbestemmelse. Hvor det ofte gentagede slagord for 2011-protesterne - I representerer os ikke! - nok er negativt og uden konkret politisk alternativ, så bevidner opkomsten af ikke-hierarkiske, autonome organisationsformer (hvilke vil blive uddybet $\mathrm{i}$ afsnit IV), at protesternes politiske alternativ snarere skal findes i deres institutionelle frembringelser: Protesten som selvorganisering.

Protesterne i Europa og USA har haft relativt tilsvarende forløb: Demonstrationerne fra 2011 og frem startede oftest på grund af konkrete politiske utilfredsheder over manglende jobs, stigende ulighed, boligudsættelser, nedskæringer på velfærdsydelser og offentlig gæld. I alle tilfælde er protesterne gået fra forholdsvis traditionelle'plads-demonstrationer' (Syntagma, Puerta del Sol, Zuccotti Park) til bredere politiske initiativer med vægt på nabolagsforsamlinger, arbejdspladsdemokratier og lokale initiativer. Således har protesterne medført mere permanente, selvorganiserede institutioner, der har taget hånd om utilfredshederne gennem politiske og 
sociale initiativer. Der er således oprettet et væld af initiativer for genhusning af ofrene for boligudsættelserne, gratis undervisning, folkekøkkener, sociale ydelser, selvstyrende fabrikker, koorperativer og lokale forsamlinger, der på forskellig vis debatterer presserende politiske problemstillinger (Sitrin \& Azzellini, 2014). Hvor protesten som begivenhed er en (negativ eller positiv) uregerlig negation af det bestående, så peger protesten som selvorganisering og de mange lokale politiske initiativer og organisationsformer videre end det etablerede systems deltagelsesmuligheder og skitserer konturerne af nye organisationsformer.

Hvad indeholder idéen om protesten som selvorganisering? Hvilke institutioner og politiske værdier står centralt? Disse spørgsmål kan belyses via den rådsdemokratiske tradition, som den findes hos Arendt og Castoriadis, der begge ønsker at forstå hvordan den umiddelbare protest formaliseres i decentrale og autonome råd. Det er blandt andet Arendts argument, at denne decentrale og deltagelsesorienterede selvorganisering fremkommer spontant i de moderne revolutioner og oprør. Er det en genaktualisering af den rådsdemokratiske organisationsform og tanke, vi ser i disse år?

III

Rådsdemokratiske praksisser, institutioner og idéer kan spores tilbage til forskellige historiske begivenheder. Således mener Arendt, at den første rådsdemokratiske formation opstod ved den Amerikanske Revolutions lokale borgermøder (townhalls) og anser Thomas Jefferson med hans idé om en decentral'nabolagsrepublik' (ward republic) for rådsdemokratiets førstefortaler (Arendt, 2012, s. 245-252). Andre ser Pariserkommunens decentralisering af politisk beslutningskompetence som rådsdemokratiets første opblomstring (Castoriadis, 1988), hvor Karl Marx' fortolkning af kommunens organisering derfor står centralt (Marx, 1996), mens endnu andre henviser til oprettelsen af arbejderråd (sovjetterne) i de russiske revolutioner i 1905 og 1917 (Anweiler, 1974). På trods af disse uenigheder om rådsdemokratiets præcise fødsel er der enighed om, at rådene er opstået i politiske kriser. Nabolagsog arbejderrådene er kontinuerligt opstået spontant og uden koordination under demonstrationer, strejker og blokader, men er sjældent forsvundet 
umiddelbart efter selve protesthandlingen. Selvom Vladimir Lenin i 1905 mente - i overensstemmelse med Žizek og Badious evalueringer af nutidens protester - at arbejderrådene udelukkende var omstyrtende organer og ikke egnet til permanent, demokratisk selvorganisering, opfattede rådene oftest sig selv som blivende organer for demokratisk selvbestemmelse, da de blev ved med at organisere fabrikkerne og nabolagene efter den politiske krise var ovre (Anweiler, 1974, s. 4; Medearis, 2004). Den kontinuerlige opblomstring af selvorganiserede råd og deres forsøg på at etablere permanente fora for politisk deltagelse, fik således en ung Antonio Gramsci til at udbryde, at "Rådet er den form arbejderklassen etablerer i bestræbelserne efter frihed. Rådet er arbejderklassens naturlige form for selvorganisering" (Gramsci, 1994, s. 179). I den forstand - og i modsætning til fortolkningerne af protesten som begivenhed - kan den rådsdemokratiske tradition fungere som et prisme at forstå de nuværende protester igennem.

I Arendts analyse i Om revolution ${ }^{5}$ (1963) af den revolutionære tradition fra de tidlige borgerlige revolutioner og frem ser hun den kontinuerlige genkomst af en distinkt rådsinstitution. Gang på gang er de samme institutioner opstået: Lokale, decentrale råd og kommuner med direkte deltagelse, repræsentation med øjeblikkelig tilbagekald og bred folkelig selvorganisering (Arendt, 2012, s. 258). Ifølge Arendt producerer rådene en alternativ politisk virkelighed og løsriver sig fra det etablerede system:

\footnotetext{
Rådene var åbenlyst rum for frihed. Som sådan vægrede de sig uvægerligt mod at blive betragtet som revolutionens midlertidige kamporganer, idet de tværtimod af alle kræfter forsøgte at etablere sig som blivende statsorganer [...] Her var der ikke tale om et paradis på jord, om et klasseløst samfund, en drøm om et socialistisk eller kommunistisk broderskab, men oprettelsen af 'den sande republik'. (Arendt, 2012, s. 260)
}

Rådene for Arendt kombinerer således to centrale karakteristika: For det første er rådene ikke midlertidige organer, der forsvinder, når protesten er ovre. De er derimod permanente organer for selvorganiseret politik; rådene opstår gennem "en pludselig desintegration af den gamle magt [...] og på samme 
tid den forbløffende dannelse af en ny magtstruktur, hvis eksistens ikke skyldtes andet end de organisatoriske impulser hos folket selv" (Arendt, 2012, s. 253). For det andet er rådene institutioner for frihed, hvilket for Arendt er tæt forbundet med politisk deltagelse. I rådstraditionens forståelse af politisk frihed som deltagelse ligger således også en kritik af det repræsentative demokrati og den rolle, som individet bliver tildelt som vælger uden mulighed for reel indflydelse:

\begin{abstract}
Rådene siger: Vi ønsker at deltage og vil vi debattere. Vi ønsker at gøre vores holdninger gældende i den offentlige debat og vi ønsker at have indflydelse på den politiske kurs i vores land [...] Stemmeboksen, hvor vi afgiver vores stemme er ubestrideligt for lille, for der er kun plads til én person. Partierne er fuldstændig uegnede; her er de fleste af os blot manipulerbare vælgere. (Arendt, 1972, s. 232-233)
\end{abstract}

Rådstraditionen i Arendts analyse deler således et centralt karakteristika med nutidens protester, nemlig kritikken af den manglende mulighed for indflydelse. Derudover er rådenes modsvar til denne fremmedgørelse ligesom de mange civilsamfundsinitiativer 2011-protesterne har medført - netop lokal selvorganisering, demokratisk kontrol og opfattelsen af frihed som muligheden for at deltage $i$ politik og ikke blot som frihed fra politik. Kort sagt: Protesten som selvorganisering og begyndende løsrivelse fra det etablerede politiske system.

På et centralt punkt er Arendts analyse af rådstraditionen dog uegnet som optik til at forstå nutidens politiske protester. Da Arendt kategorisk skelner mellem det sociale, privatlivet og økonomien på den ene side og den politiske sfære på den anden side, og således forstår økonomiske forhold som apolitiske, misforstår hun til tider rådstraditionen. Rådstraditionens "dårlige ry" er således netop ifølge Arendt, at "rådene på fabrikkerne bragte et element af handling ind i ledelsen af ting og det kunne kun skabe kaos" (Arendt, 2012, s. 270). Handling er for Arendt knyttet til frihed, hvorimod administrationen af ting - økonomien - er forbundet til frihedens modsætning, nemlig nødvendighed (Arendt, 2005, s. 54-62), hvorfor politisk handling på nødvendighedens domæne ifølge Arendt er dømt til at slå fejl. 
Modsat Arendts teoretiske opdelinger, så var den kontinuerlige oprettelse af råd under de moderne revolutioner fra Den Amerikanske Revolution og frem - og særligt i det 20. århundrede - ledsaget af kollektiv selvorganisering på arbejdspladsen, på fabrikkerne, i industrien og i landbruget. Rådstraditionen er således historisk set en økonomisk-politisk tradition, der udfordrer det skel mellem politik og økonomi, som både liberal politisk teori og Arendts tænkning bygger på. En sådan adskillelse er simpelthen en historisk tvivlsom analyse af rådstraditionens praksisser (McConkey, 1991; Medearis, 2004), og set ud fra nutidens protester også en ufrugtbar analyse, da kritikken af økonomiske forhold åbenlyst er en del af protesternes formål - for eksempel i kritikken af bankpakkerne i både USA og Europa efter krakket på Lehman Brothers i 2008 eller i påpegningen af den ekstreme økonomiske ulighed i parolen Vi er de 99 procent!.

Selvom Arendt leverer den grundlæggende analyse af rådstraditionens opståen og principper, så skal hendes analyse suppleres af et perspektiv, der vedkender at de mest udbredte råd var arbejder- og fabriksråd - altså selvorganiseringsformer, der ikke, som hun, skelnede mellem økonomi og politik.

Et sådan supplement leverer den græsk-franske tænker Cornelius Castoriadis som det klareste eksempel. Castoriadis var hovedmanden bag den indflydelsesrige socialistiske gruppe Socialisme ou Barberie, der fra 1949 til 1965 udgav et tidsskrift af samme navn. Castoriadis var åben kritiker af det kommunistiske projekt, som det udfoldede sig i Sovjetunionen, og kritiserede systemet for dets fremmedgørende bureaukrati, centralistiske magtstruktur og kontinuerlige udbytning af arbejderne. Castoriadis agiterede herimod for autonomi, for at socialismens kerneidé var demokrati forstået som arbejdernes selvbestemmelse over deres egne liv (Breckman, 2013, s. 102).

I en række tekster fra 1956-1957, dvs. lige efter Den Ungarske Revolution i 1956, der også inspirerede Arendts analyse af rådstraditionen, analyserede Castoriadis det 20. århundredes arbejder- og fabriksråd i lyset af sit autonomiprojekt. Castoriadis' projekt anerkender åbenlyst ikke Arendts skelnen mellem den økonomiske og den politiske sfære: "At have udelukkende politisk autonomi er meningsløst. Man kan ikke forestille sig et samfund, hvor folk er slaver i produktionen til hverdag, og derefter nyder den politiske frihed om søndagen” (Castoriadis, 1988, s. 101). Castoriadis' analyse af 
rådsfænomenet og dets opblomstring $\mathrm{i} ø$ konomien er derimod, at hvis mennesket skal leve autonomt, så skal det kunne kontrollere de institutioner, det lever under - herunder de økonomiske. Uden kontrol ingen autonomi og dermed ingen frihed. Da menneskets økonomiske forhold i allerhøjeste grad påvirker det individuelle liv, så indebærer autonomi også kontrol over økonomien. Kontrol og indflydelse - og altså autonomi og frihed - kan ikke uddelegeres, politisk magt og initiativ kan ikke fremmedgøres. Ingen kan være autonom på andres vegne; at bestemme betyder at bestemme selv, idet reelt demokrati:

forudsætter folkets selvorganisering af alle aspekter af det sociale liv [...] At bestemme betyder at bestemme selv. At afgøre hvem der skal bestemme, er allerede ikke at bestemme selv. Den eneste absolutte form for demokrati er derfor direkte demokrati [...]. For at opnå det bredeste, mest meningsfulde direkte demokrati kræves det, at alle økonomiske og politiske strukturer samt andre strukturer i samfundet baseres på lokale grupper, dvs. konkrete fællesskaber og organiske sociale enheder. (Castoriadis, 1988, s. 95, 98)

Derfor bliver rådenes selvorganisering for Castoriadis det princip, der sikrer individets autonomi i alle sociale relationer: "Den basale sociale enhed (rådet), som vi har beskrevet den indtil nu, vil ikke blot administrere produktionen. Rådet vil samtidigt og primært være enheder for folkelig selvorganisering $i$ alle dets aspekter" (Castoriadis, 1988, s. 136).

IV

Rådstraditionen indeholder således for det første en specifik genese, for det andet en række politiske værdier og for det tredje en distinkt opfattelse af, hvordan disse værdier opretholdes.

Rådene er opstået spontant i kriser og omvæltninger som folkelig selvorganisering; værdimæssigt og ideologisk betoner rådene direkte politisk deltagelse, frihed til politik og folkelig indflydelse som modsvar til det repræsentative demokratis opdeling mellem regerende og regerede og den 
tiltagende apati på de regeredes side. Endelig understreger rådstraditionen, at lokale og decentrale fællesskaber med udstrakt beslutningskompetence, selvbestemmelse og autonomi, er den gavnligste institutionelle konstruktion til at sikre disse værdier.

I det følgende vil jeg kort udlægge en række initiativer, der er vokset ud af nutidens protester, for derefter at diskutere disse i lyset af rådsdemokratiets centrale karakteristika som fremlagt i det ovenstående.

De politiske initiativer, der er fremvokset af protesterne, har antaget forskellige former, men har fundamentalt set handlet om at opnå selvbestemmelse og kontrol gennem decentral selvorganisering. I 2013 genåbnede en række græske arbejderorganisationer, eksempelvis gældsplagede og nedlagte fabrikker, hvor man genoptog produktionen og styrede fabrikkernes anliggender kollektivt. I en deklaration til omverdenen fremlagde organisationerne deres formål:

\begin{abstract}
Vi tager ansvaret for fabrikken $\mathrm{i}$ form af fuld selvforvaltning og arbejderkontrol over både de producerende og de administrative strukturer. Det grundlæggende og centrale princip i driften af fabrikken, i den kamp vi driver, og kernebegreberne i vores fremtidige planer, er lighed i deltagelse og beslutningstagning, horisontalitet og direkte demokrati. (Kioupkiolis \& Katsambekis, 2014, s. 1)
\end{abstract}

Overtagelsen af nedlagte fabrikker og indførelsen af selvforvaltende arbejdspladser følger direkte af kritikken af gældskrisen, bankerne og det repræsentative demokrati, som nutidens protester har gjort central. Besættelsen af nedlagte fabrikker og indførelsen af demokratiske beslutningsmåder har i 2000'erne været praktiseret som modsvar til neoliberalismen i latinamerikanske lande (Bonnet, 2014) og var derudover en central praksis i de rådsdemokratiske eksperimenter i mellemkrigstidens Europa.

Ligeledes, i relation til boligudsættelser, der er en af de mest åbenlyse konsekvenser af den finansielle krise, har de spontane protester formaliseret sig i konkrete politiske initiativer. Fra den spanske paraplyplatform PAH (Plataform de Afectados por la Hipoteca) til Occupy Our Homes-initiativet i USA, der er en udløber af Occopy Wall Street-bevægelsen, har lokale politiske initiativer bekæmpet husudsættelserne og i flere tilfælde skabt mærkbare 
resultater (Prentoulis \& Thomassen, 2014, s. 230). Disse konkrete politiske initiativer, "der er organiseret i løse netværk af lokale bevægelser, er fortsat i samme stil som de oprindelige indignados-protester og har således horisontal organisation som centralt organisationsprincip" (Prentoulis \& Thomassen, 2014, s. 230). Lignende initiativer, hvor civilsamfundsorganisationer har slået sig sammen i paraply- og regnbuekoalitioner med det formål at løse konkrete politiske problemer gennem lokal selvorganisering, er vokset frem mange steder, hvor protesterne har mobiliseret og organiseret almindelige mennesker i deres lokalmiljø. På baggrund af deres mange interviews med demonstranter fra Spanien, Grækenland, USA, Argentina og Venezuela slår Marina Sitrin og Dario Azzellini fast, at "hierarki og repræsentativt demokrati bliver afvist, både ideologisk og praktisk, og via denne afvisning åbner massebaserede, horisontale forsamlinger for nye politiske landskaber baseret på frihed og autonomi” (Sitrin \& Azzellini, 2014, s. 5-6). Sitrin og Azzellinis henviser direkte til rådstraditionen, når de selvorganiserede initiativer skal beskrives:

De nye eksperimenter med deltagelse omfatter råd (kommunale råd, arbejderråd, studenterråd, landbrugsråd, kvinderåd osv.) [...] Rådene konstruerer en ikke-repræsentativ struktur med direkte deltagelse, der eksisterer parallelt med de etablerede repræsentative organer. (Sitrin \& Azzellini, 2014, s. 213, 219)

Også Saul Newman, der har beskæftiget sig indgående med anarkistisk praksis og radikal demokratiteori, beskriver initiativerne og eksperimenterne med selvorganisering - i overensstemmelse med Castoriadis' autonomiprojekt som den autonome selvforvaltning af borgernes politiske liv, idet protesterne er "autonom politik [...] der peger på mulighederne for autonome sociale relationer og politisk sameksistens ved siden af og udover det finansielle systems konkursramte despotisme og det repræsentative demokratis nihilistiske paradeforestilling" (Newman, 2014, s. 93).

Protesterne, i Newmans optik, bevæger sig præcis fra begivenhed til selvorganisering, idet de gradvist gennem selvorganiseringen løsriver sig fra det etablerede politiske system (Newman, 2014, s. 94).

Så hvordan skal protesterne forstås? Som begivenheder? Det vil sige som 
vredesudbryd uden relevans for det politiske system og ødelæggende for den demokratiske proces, som Krastev forstår dem? Eller som omstyrtende momenter, der mestendels henleder opmærksomheden på det repræsentative demokratis mangler, som Žizek og Badiou vil det? Eller skal protesternes forstås som selvorganisering; som den gradvise konstruktion af inkluderende og horisontale institutioner baseret på direkte deltagelse, lokal selvbestemmelse og demokratisk kontrol?

Distinktionen mellem begivenhed og selvorganisering er nok tegnet skarpt op og nutidens protester indeholder elementer af begge perspektiver. Men ved at koncentrere analysen af protesterne omkring selvorganiserede, autonome politiske initiativer bliver det tydeligt, at protesterne og de demokratiske eksperimenter, vi er vidne til i disse år deler flere centrale karakteristika med den rådsdemokratiske tradition - endda i en sådan grad, at protesternes selvorganisering kan ses om genaktualiseringer af rådsdemokratiske idealer. Protesterne er åbenlyst opstået i midten af krisen - både en økonomisk krise, men også en politisk krise, der bestrider legitimiteten af det politiske system gennem folkelig selvorganisering. Protesterne baserer sig, ligesom rådsidéen, på direkte politisk deltagelse og autonomi - på idéen om, at autonomi opnås gennem reel folkelig kontrol. Endelig organiserer de mange politiske initiativer sig på mange måder ligesom rådene, nemlig lokalt og gennem sammenkoblingen af heterogene bevægelser og regnbuekoalitioner.

Protesterne kan således siges at aktualisere det rådsdemokratiske ideal om politisk frihed: Kun ved at deltage politisk og medvirke til at skabe de institutionelle rammer for det fælles liv, kan frihed opnås. Dette kan per definition ikke uddelegeres eller varetages af repræsentanter. Eller som Arendt siger det, så fordrer rådstraditionen - og måske også nutidens protester - at "ingen kunne være lykkelig eller fri uden at deltage og have en andel i den offentlige magt" (Arendt, 2012, s. 251).

At se nutidens protester som en aktualisering af det rådsdemokratiske ideal om autonomi og politisk frihed er dog ikke en omkostningsløs sammenligning. Som Arendt rigtigt bemærker (2012, s. 261-262), og som historien også bevidner, eksisterede rådsformationerne under de moderne revolutioner fra Den Amerikanske Revolution og frem på trods af ambitionen om permanent selvorganisering sjældent særlig længe, da de autonome politiske 
strukturer oftest blev direkte ødelagt af de politiske partier og professionelle revolutionære. ${ }^{6}$ Man etablerer ikke konkurrerende politiske strukturer uden at det etablerede system reagerer med modstand, hvilket synes at være den centrale historiske erfaring for rådsdemokraterne. En genaktualisering af rådstraditionen er således også en genaktualisering af (muligheden for) et nederlag eller hvad Arendt kalder den revolutionære traditions tabte arv. Men netop fordi denne arv er tabt - fordi traditionen eksisterer, men er glemt - kalder den nuværende politiske og økonomiske krise på behovet for en genaktualisering af det rådsdemokratiske ideal og protesternes selvorganisering tydeliggør, at politisk frihed og demokratisk deltagelse aldrig er statiske tilstande, men idealer, der kontinuerligt kan tilnærmes gennem folkelig selvorganisering.

NOTER

1 Jeg vil gerne takke tidsskriftets temaredaktion og de anonyme reviewere for kritiske og konstruktive kommentarer.

2 Listen over paroler fra protesterne i 2011-2012 er taget fra Sitrin og Azzellini (2014).

3 'Exit' og 'voice' - begreber, der bruges af Krastev selv - henviser til Albert O. Hirschmans klassiker Exit, Voice and Loyalty (1970), hvor exit præger individets ageren på markedet - kan man ikke lide et produkt, køber man et andet - og voice kendetegner den demokratiske handlingsmåde, hvor problemer løses via deliberation.

4 Det tvivlsomme i Krastevs analogi består i, at han ikke nævner, at plebejerne igennem denne exit-strategi fik øget deres politiske rettigheder betydeligt, da de kun vendte tilbage til Rom - og til det arbejde, der var nødvendigt for opretholdelsen af patriciernes levestandard - under forudsætning af indstiftelsen af klassespecifikke politiske institutioner for deltagelse og repræsentation.

5 I Mikkel Thorups efterskrift til den danske oversættelse af On Revolution fra 2012 kalder han det Arabiske Forår for "det fineste eksempel på bogens forsatte aktualitet" og beskriver de arabiske opstande som følgende den samme skabelon som rådenes oprettelse: "De [de arabiske opstande] opstod tilsyneladende ud af intet. Det var befolkningen selv, ikke partier eller organisationer, der mobiliserede. Spontan selvorganisering synes at være handlingsprincippet" (Thorup, 2012, s. 352, min kursivering).

6 Det klassiske eksempel er Den Russiske Revolution, hvor Lenin proklamerede 'al magt til sovjetterne', for efter revolutionen at gøre arbejderrådene fuldstændig underordnede det kommunistiske parti. 
Anweiler, O. (1974). The Soviets: The Russian Workers, Peasants, and Soldiers Councils, 1905-1921. New York: Pantheon Books.

Arendt, H. (1958). Totalitarian imperialism: Reflections on the Hungarian revolution. The Journal of Politics, 20(01), 5-43. doi:10.2307/2127387

Arendt, H. (1972). Crises of the Republic. New York: Harcourt Brace Jovanovich.

Arendt, H. (2005). Menneskets vilkår. København: Gyldendal.

Arendt, H. (2012). Om revolution. Aarhus: Klim.

Badiou, A. (2012a). Metapolitics. London: Verso.

Badiou, A. (2012b). The Rebirth of History: Times of Riots and Uprisings. London: Verso.

Bonnet, A. (2014). The Idea of Councils Runs through Latin America. South Atlantic Quarterly, 113(2), 271-283. doi:10.1215/00382876-2643612

Breckman, W. (2013). Adventures of the Symbolic: Post-Marxism and Radical democracy. New York: Columbia Univesity Press.

Castoriadis, C. (1988). Political and Social Writings: Vol. 2. Minneapolis: University of Minnesota Press.

Gramsci, A. (1994). Pre-Prison Writings. Cambridge: Cambridge University Press.

Hirschman, A. (1990). Exit, Voice and Loyalty: Responses to Decline in Firms, Organizations and States. Cambridge: Harvard University Press.

Krastev, I. (2014). Democracy Disrupted: The Politics of Global Protest. Philadelphia: University of Pennsylvania Press.

Marx, K. (1996). Later Political Writings. Cambridge: Cambridge University Press.

McConkey, M. (1991). On Arendt's vision of the European council phenomenon: Critique from an historical perspective. Dialectical Anthropology, 16(1), 15-31. doi:10.1007/ bf00247767

Medearis, J. (2004). Lost or Obscured? How V. I. Lenin, Joseph Schumpeter, and Hannah Arendt Misunderstood the Council Movement. Polity, 36(3), 447-476.

Newman, S. (2014). Occupy and Autonomous Political Life. I A. Kioupkiolis \& G. Katsambekis (red.), Radical Democracy and Collective Movements Today: The Biopolitics of the Multitude versus the Hegemony of the People (s. 93-111). Burlington: Ashgate Publishing Company.

Prentoulis, M. \& Thomassen, L. (2014). Autonomy and Hegemony in the Squares: The 2011 Protests in Greece and Spain. I A. Kioupkiolis \& G. Katsambekis (red.), Radical Democracy and Collective Movements Today: The Biopolitics of the Multitude versus the Hegemony of the People (s. 213-234). Burlington: Ashgate Publishing Company.

Sitrin, M. \& Azzelini, D. (2014). They Can't Represent Us!: Reinventing Democracy from Greece to Occupy. London: Verso.

Thorup, M. (2012). Om Arendt og revolutionerne - Efterskrift. I Om Revolution (s. 333359). Aarhus: Klim.

Žižek, S. (2012). The Year of Dreaming Dangerously. London: Verso.

Žižek, S. (2014). Event: Philosophy in Transit. New York: Penguin. 

